\title{
Milk Consumption Correlates with Body Height in Children
}

\author{
Evan Tirtasaputra*, Grace Puspasari**, Teresa Lucretia*** \\ *Faculty of Medicine Maranatha Christian University \\ **Department of Biochemistry Faculty of Medicine \\ Maranatha Christian University \\ ***Department of Histology Faculty of Medicine Maranatha Christian University \\ Jl. Prof. drg. Suria Sumantri MPH No.65 Bandung 40164 Jawa Barat Indonesia \\ Email : evan.tirtasaputra@gmail.com
}

\begin{abstract}
Growth in children is very important because it affects a person's height as an adult. Qualified and adequate nutrition play a significant role in growth. Adequate milk consumption can affect bone growth which ultimately affects height and helps reduce the risk of bone loss. The purpose of this study was to determine the correlation between milk consumption and height in children. This study is an analytic observational study, involving 126 subjects aged 69 years from an elementary school in Bandung. The sample was taken by whole sampling technique. Data collection was carried out using questionnaires and height measurements. The data was analyzed using the Gamma correlation test. The statistical results showed a significant relationship between the frequency of milk consumption and height $(p=0.044)$ with a medium correlation coefficient $(r=0.430)$ and a positive correlation direction which meant an increase in the frequency of milk consumption along with the increasing height in children aged 6-9 years. We concluded that milk consumption correlates with body height in children.
\end{abstract}

Keywords: milk consumption, body height, children, correlation 


\title{
Konsumsi Susu Berkorelasi dengan Tinggi Badan Pada Anak
}

\author{
Evan Tirtasaputra*, Grace Puspasari**, Teresa Lucretia*** \\ * Fakultas Kedokteran Universitas Kristen Maranatha \\ **Bagian Histologi Fakultas Kedokteran Universitas Kristen Maranatha \\ ***Bagian Patologi Anatomi Fakultas Kedokteran Universitas Kristen Maranatha \\ Jl. Prof.Drg.Surya Sumantri, MPH No 65 Bandung 40164 Indonesia \\ Email : evan.tirtasaputra@gmail.com
}

\begin{abstract}
Abstrak
Pertumbuhan pada anak sangat penting karena memengaruhi tinggi badan seseorang ketika dewasa. Nutrisi yang berkualitas dan adekuat berperan dalam pertumbuhan. Konsumsi susu yang adekuat dapat memengaruhi pertumbuhan tulang yang pada akhirnya memengaruhi tinggi badan dan membantu mengurangi risiko kehilangan massa tulang. Tujuan penelitian ini adalah untuk mengetahui korelasi konsumsi susu dengan tinggi badan pada anak. Penelitian ini merupakan penelitian observasional analitik. Penelitian ini melibatkan 126 subjek berusia 6-9 tahun dari sebuah sekolah dasar di Bandung, pengambilan subjek dilakukan dengan teknik whole sampling. Pengumpulan data dilakukan menggunakan kuesioner dan pengukuran tinggi badan. Hasil pengumpulan data dianalisis menggunakan uji korelasi Gamma. Hasil uji statistik menunjukkan hubungan signifikan antara frekuensi konsumsi susu dan tinggi badan $(p=0,044)$ dengan koefisien korelasi sedang $(r=0,430)$ dan arah korelasi positif yang berarti peningkatan frekuensi konsumsi susu seiring dengan meningkatnya tinggi badan pada anak usia 6 - 9 tahun. Simpulan penelitian ini adalah terdapat hubungan signifikan antara frekuensi konsumsi susu dan tinggi badan pada anak.
\end{abstract}

Kata kunci: konsumsi susu, tinggi badan, anak, korelasi 


\section{Research Article}

\section{Pendahuluan}

Usia anak merupakan fase yang penting untuk terjadinya pertumbuhan linear hingga mencapai puncak percepatan pertumbuhan pada saat pubertas. Pertumbuhan pada usia tersebut dipengaruhi oleh berbagai hal, salah satunya adalah pemberian nutrisi yang berkualitas dan adekuat. Menurut data Riskesdas tahun 2013, prevalensi anak usia 5 - 12 tahun yang memiliki tubuh pendek adalah 30,7 \% (12,3\% sangat pendek dan 18,4\% pendek). Pemantauan Status Gizi (PSG) 2015, sebesar 29\% balita Indonesia termasuk kategori pendek, dengan persentase tertinggi di Provinsi Nusa Tenggara Timur dan Sulawesi Barat. Menurut World Health Organization (WHO), prevalensi balita pendek menjadi masalah kesehatan masyarakat jika prevalensinya $20 \%$ atau lebih. Data ini menunjukkan bahwa adanya masalah gizi sejak masa bayi/balita, termasuk penyakit yang diderita selama masa balita sehingga masih banyak anak Indonesia yang tidak mencapai tinggi badan ideal. ${ }^{1,2}$

Pada usia 6 - 9 tahun pertumbuhan anak dalam kondisi yang stabil dikarenakan pada periode postnatal growth spurt, rate atau kecepatan dari pertumbuhan linear menurun secara progresif. Kemudian, kecepatan pertumbuhan linear akan meningkat kembali secara progresif pada saat onset pubertas hingga mencapai usia 18 tahun, yang dikenal sebagai pubertal growth spurt. $^{3}$ Pertumbuhan tulang dipengaruhi oleh faktor intrinsik dan ekstrinsik. Faktor intrinsik yaitu faktor genetik dan hormon, faktor ini berperan hingga $80 \%$ dari pertumbuhan tulang. Faktor ekstrinsik yaitu aktivitas fisik dan nutrisi. Nutrisi yang berperan dalam pertumbuhan tulang antara lain mineral dan vitamin. ${ }^{3,4}$

Konsumsi susu yang adekuat dapat memengaruhi pertumbuhan tulang yang pada akhirnya memengaruhi tinggi badan dan membantu mengurangi risiko kehilangan massa tulang. ${ }^{5}$ Susu merupakan salah satu sumber energi, protein dan mineral. Sumber energi diperoleh dari laktosa dengan kandungan energi mencapai 274 kJ atau 66 kkal. ${ }^{6}$ Protein pada susu sapi seperti kasein, whey, dan asam amino dapat menstimulasi pembentukan insuline like growth factor-1 (IGF-1) yang berperan dalam proliferasi kondrosit dan osteoblas serta pembentukan matriks jaringan tulang. ${ }^{7}$ Kandungan mineral dalam susu seperti kalsium, magnesium, selenium, riboflavin, vitamin $\mathrm{B}_{12}$, dan asam pantotenat dapat memberikan kontribusi yang signifikan untuk memenuhi nutrisi yang diperlukan. Sumber makanan hewani, termasuk susu dapat menjadi sumber seng dan vitamin $\mathrm{B}_{12}$ yang penting untuk mencegah defisiensi nutrisi pada anak - anak. ${ }^{8}$

Penelitian Hardinsyah menunjukkan bahwa adanya hubungan positif antara lamanya kebiasaan minum susu dengan tinggi badan pada remaja usia 16-17 tahun. Penelitian lainnya menyatakan bahwa adanya hubungan bermakna antara kecukupan kalsium dari susu dan tinggi 


\section{Research Article}

badan anak..$^{9-11}$ Penelitian sebelumnya kebanyakan mengikutsertakan usia remaja, diduga pada usia remaja ada pengaruh pubertas sehingga dapat menghasilkan perbedaan tinggi badan yang bias karena adanya pengaruh hormon menyebabkan perbedaan kecepatan pertumbuhan setiap orang, sedangkan penelitian terhadap anak usia 6 - 9 tahun yang merupakan usia sebelum pubertas belum pernah dilakukan., ${ }^{4-9-14}$ Tujuan penelitian ini adalah untuk mengetahui hubungan antara frekuensi konsumsi susu dengan tinggi badan seorang anak usia 6 - 9 tahun.

\section{Metode}

Penelitian ini bersifat observasional analitik, dengan teknik pengambilan sampel secara potong lintang (cross sectional) terhadap data tinggi badan dan frekuensi konsumsi susu di sebuah SD di Kota Bandung. Penelitian ini telah mendapat persetujuan dari Komisi Etik Penelitian (KEP) Fakultas Kedokteran Universitas Kristen Maranatha - Rumah Sakit Immanuel dengan surat keputusan nomor 121/KEP/III/2018. Populasi pada penelitian ini adalah seluruh siswa kelas 1 - 3 SD yang berjumlah 126 siswa laki-laki dan perempuan yang memenuhi kriteria inklusi. Penelitian dilakukan di sebuah SD di kota Bandung. Kriteria inklusi ialah anak yang berumur 6 - 9 tahun dan sehat secara jasmani. Kriteria eksklusi ialah anak yang memiliki riwayat penyakit kronis seperti batuk lama berdasarkan kuesioner dan anak yang tidak hadir saat pengambilan data.

Pengukuran tinggi badan dilakukan menggunakan staturemeter dengan ketelitian 0,1 $\mathrm{cm}$ dan untuk data frekuensi konsumsi susu didapat melalui metode wawancara terhadap setiap siswa. Data tersebut dimasukkan kemudian dikategorikan untuk tinggi badan dikategorikan berdasarkan z-score WHO usia terhadap tinggi badan. Kategori status gizi berdasarkan TB/U terdiri atas Tinggi jika nilai Z-Score $\geq 2,0 \mathrm{SD}$, Normal jika nilai Z-Score - 2,0 $<\mathrm{Z}<2,0 \mathrm{SD}$, dan Pendek jika nilai Z-Score $\leq-2,0$ SD. ${ }^{15-17}$ Data frekuensi konsumsi susu dikategorikan menjadi rutin dan jarang berdasarkan anjuran pedoman gizi seimbang. Kategori konsumsi susu terbagi atas rutin apabila subjek mengonsumsi susu $\geq 1$ porsi per hari atau total konsumsi susu $\geq 7$ porsi per minggu dan jarang apabila subjek mengonsumsi susu $<1$ porsi per hari atau total konsumsi susu $<7$ porsi per minggu. ${ }^{18}$ Data kemudian dianalisis menggunakan uji korelasi Gamma dengan $\alpha=0.05$ dengan tujuan untuk melihat adanya hubungan frekuensi konsumsi susu dengan tinggi badan menggunakan SPSS versi 24.

\section{Hasil}

Subjek penelitian berjumlah 126 orang yang memenuhi kriteria inklusi yang terdiri atas 68 siswa laki-laki dan 58 siswa perempuan. Setelah dilakukan analisis data mengenai hubungan 
riwayat frekuensi konsumsi susu dengan tinggi badan, didapatkan hasil yang tercantum dalam tabel 1.

Tabel 1 Hubungan Frekuensi Konsumsi Susu dengan Tinggi Badan

\begin{tabular}{|c|c|c|c|c|c|}
\hline \multirow{2}{*}{$\begin{array}{c}\text { Frekuensi } \\
\text { Susu }\end{array}$} & \multicolumn{3}{|c|}{ Tinggi Badan } & \multirow[b]{2}{*}{$\mathrm{r}$} & \multirow[b]{2}{*}{$\mathrm{p}^{*}$} \\
\hline & Pendek & Normal & Tinggi & & \\
\hline Jarang & 14 & 32 & 1 & \multirow{3}{*}{0,430} & \multirow{3}{*}{0,044} \\
\hline Rutin & 10 & 68 & 1 & & \\
\hline Total & 24 & 100 & 2 & & \\
\hline
\end{tabular}

Dari tabel diatas didapatkan hasil uji korelasi nonparametrik Gamma dengan koefisien korelasi " $\mathrm{r}$ " 0,430 dan nilai $\mathrm{p}=0,044$, yang berarti terdapat korelasi yang searah antara konsumsi susu dengan tinggi badan yang bermakna. Hal ini menunjukkan bahwa frekuensi konsumsi susu yang rutin seiring dengan kenaikan tinggi badan. Korelasi pada penelitian ini termasuk kategori sedang dengan " $r$ " $0,430(r=0,4-<0,6)$.

\section{Diskusi}

Berdasarkan pengolahan data penelitian ini, didapatkan bahwa hasil penelitian ini sesuai dengan yang didapatkan oleh para peneliti sebelumnya yaitu Hardinsyah dkk. yang mendapatkan hubungan positif antara tinggi badan dengan frekuensi minum susu dan jumlah susu yang dikonsumsi. Hasil penelitian menunjukkan rata-rata konsumsi susu subjek adalah 170 $\mathrm{ml} /$ hari dengan frekuensi 6 kali/minggu. Hasil penelitian ini juga sesuai dengan penelitian Ernawati yang mendapatkan adanya korelasi yang positif antara frekuensi dan jumlah konsumsi susu dengan tinggi badan pada anak sekolah TK. Hasil penelitian menunjukkan anak yang setiap hari minum susu mempunyai tinggi badan yang lebih tinggi $\pm 4.29 \mathrm{~cm}$ dibandingkan dengan anak yang jarang minum susu. ${ }^{9,10}$

Proses pembentukan tulang disebut osifikasi atau osteogenesis dimulai sejak embrio berusia 6 minggu. Terdapat dua jenis osifikasi, pertama osifikasi intramembranosa yaitu pembentukan tulang dari diferensiasi sel mesenkim menjadi osteoblast yang kemudian menghasilkan matriks tulang dan membentuk struktur trabekula tulang. Kedua, osifikasi endokhondralis yang terjadi pada kartilago hialin yang merupakan cetakan untuk tulang yang akan dibentuk. Jenis osifikasi ini bertanggung jawab terhadap sebagian besar pembentukan tulang pada tubuh termasuk tulang panjang., ${ }^{4,19}$ Peran kalsium dalam pembentukan tulang adalah untuk menghasilkan matriks ekstraseluler dan untuk pengerasan tulang. Kekurangan asupan kalsium dapat menyebabkan rendahnya massa tulang yang 


\section{Research Article}

berakibat pada terjadinya osteomalasia yaitu tulang yang lunak dan rapuh, sehingga mudah mengalami patah tulang. Kelebihan asupan kalsium dapat menyebabkan hiperkalsemia yang berakibat pada kalsifikasi berlebihan pada jaringan lunak, terutama ginjal serta mengganggu penyerapan mineral lain seperti besi, seng, dan mangan. ${ }^{20}$

Susu mengandung mineral yang penting untuk pertumbuhan tulang seperti kalsium dan fosfor yang dalam bentuk ion akan membentuk hidroksiapatit yang berfungsi untuk pertumbuhan massa dan kepadatan tulang yang optimal. Mineral lain yang dibutuhkan dalam jumlah sedikit antara lain magnesium yang berfungsi membantu pembentukan matriks ekstraseluler dan sebagai physiologic calcium-channel blocker untuk mencegah pelepasan kalsium berlebihan ke dalam darah. Fluor berfungsi membantu memperkuat matriks ekstraselular tulang. Besi dan mangan sebagai aktivator enzim untuk sintesis matriks ekstraselular. ${ }^{20}$ Kandungan mineral utama dalam 100 gram susu yaitu kalsium 120 mg dan fosfor $91 \mathrm{mg}$. Selain itu dalam susu terdapat kasein yang dapat menstimulasi pembentukan IGF1 yang berperan dalam proliferasi kondrosit dan osteoblast serta pembentukan matriks pada jaringan tulang. ${ }^{6,7}$

Banyak faktor yang mempengaruhi tinggi badan seseorang seperti faktor genetik, faktor aktivitas fisik, faktor hormonal serta faktor nutrisi seperti jenis makanan dan asupan kalsium harian yang bersumber selain dari konsumsi susu dan jenis susu tertentu secara spesifik. Namun faktor - faktor tersebut tidak diteliti dan dapat mempengaruhi hasil penelitian ini

\section{Simpulan}

Berdasarkan penelitian yang telah dilakukan, diperoleh simpulan bahwa terdapat korelasi antara frekuensi konsumsi susu dan tinggi badan pada anak.

\section{Daftar Pustaka}

1. Badan Penelitian dan Pengembangan Kesehatan. Riset Kesehatan Dasar (RISKESDAS) 2013. Lap Nas 2013. 2013;1-384.

2. Kementerian Kesehatan Republik Indonesia. Buku Saku Pemantauan Status Gizi dan Indikator Kinerja Gizi Tahun 2015. Direktorat Gizi Masyarakat Direktorat Jenderal Kesehatan Masyarakat. 2015;42-84.

3. Sherwood L. Human Physiology: From Cells to System. 9th ed. 2016. p. 652-655.

4. Tortora GJ, Derrickson B. Principles of Anatomy \& Physiology 14th Edition. Wiley. 2014. p. 169-191.

5. Lawrence A. Milk and Milk Products. In: Man J, Truswell S, editors. Essentials of Human Nutrition. Oxford University Press ; EGC; 2012. p. 390-1.

6. Wijesinha-Bettoni R, Burlingame B. Milk and dairy product composition. In: Milk and Dairy Products In Human Nutrition. Rome: Food And Agricultural Organization; 2013. p. 41-60.

7. Martin R, Holly J, Gunnell D. Milk and Linear Growth : Programming of the IGF-I Axis and Implication for Health in Adulthood. Nestle Nutr Workshop Ser Pediatr Program. 2011;67:79-97.

8. Weaver C, Wijesinha-Bettoni R, McMahon D, Spence L. Milk and dairy products as part of the diet. In: Muehlhoff E, Bennett A, McMahon D, editors. Milk and Dairy Products In Human Nutrition. Rome: Food And Agricultural Organization; 2013. p. 111.

9. Hardinsyah, Damayanthi E, Zulianti W. Hubungan Konsumsi Susu dan Kalsium dengan Densitas Tulang dan Tinggi Badan Remaja. J Gizi dan Pangan [Internet]. 2008 [Cited 2017 Dec 9];3(1):43-8. Available from: 


\section{Research Article}

http://jamu.journal.ipb.ac.id/

10. Ernawati. Hubungan Konsumsi Susu Dengan Tinggi Badan Anak Sekolah TK [Internet]. Institut Pertanian Bogor; 2013 [Cited: 28 Januari 2015]. Available from: http://repository.ipb.ac.id/jspui/bitstream/123456789/

11. Nainggolan RS, Aritonang EY, Ardiani F. Hubungan Pola Konsumsi Makanan Dan Konsumsi Susu Dengan Tinggi Badan Anak Usia 6-12 Tahun. J Gizi, Kesehat Reproduksi dan Epidemiol [Internet]. 2014 [Cited 2017 Dec 9];1(3):1-8. Available from: https://jurnal.usu.ac.id/index.php/gkre/article/viewFile/7621/4330

12. Nisa F. Hubungan Konsumsi Susu dengan Tinggi Badan dan Prestasi Belajar pada Siswa/i Di Sekolah Dasar Muhammadiyah 02 Kampung Dadap Medan [Internet]. Universitas Sumatera Utara; 2017 [Cited 2018 Mar 7 ]. Available from: http://repository.usu.ac.id/handle/123456789/67564

13. Fadhilah AU. Hubungan Tingkat Kecukupan Energi, Protein, Kalsium dan Fosfor dengan Panjang Tungkai Pada Remaja [Internet]. Hubungan Tingkat Kecukupan Energi, Protein, Kalsium dan Fosfor dengan Panjang Tungkai Pada Remaja. 2016 [Cited 2017 Dec 9]. Available from: http://ijhn.ub.ac.id/index.php/ijhn/article/view/192

14. Meikawati W, Amalia R. Hubungan Kebiasaan Minum Susu Dan Olahraga Dengan Kepadatan Tulang Remaja (Studi Di SMAN 3 Semarang). Pros Semin Nas Unimus [Internet]. 2010 [Cited 2017 Dec 23];192-7. Available from: https://jurnal.unimus.ac.id/index.php/psn12012010/article/view/77/56

15. World Health Organization (WHO). Training Course on Child Growth Assessment. Vol. WS 103, World Health Organization. Training Course on Child Growth Assessment. Geneva. 2008.

16. World Health Organization (WHO). Height-for-age Boys and Girls 5-19 years (z-scores). WHO growth reference. 2007.

17. Kementerian Kesehatan Republik Indonesia. Standar Antropometri Penilaian Status Gizi Anak. 2010. p. 40.

18. Kementerian Kesehatan Republik Indonesia. Pedoman Gizi Seimbang Permenkes RI. Pedoman Gizi Seimbang Permenkes RI. 2014;1-96.

19. Mescher AL. Junqueiras's Basic Histology Text and Atlas. Junqueiras's Basic Histology Text and Atlas. 2013. p. 343-363.

20. Mahan K, Escott S. Krause's Food \& Nutrition Therapy. 12th ed. Elsevier; 2007. p. 49-138. 